\title{
INTRODUCTION TO THE SYMPOSIUM ON SARA MCLAUGHLIN MITCHELL \& ANDREW P. OWSIAK, “JUDICIALIZATION OF THE SEA: BARGAINING IN THE SHADOW OF UNCLOS"
}

\author{
Karen J. Alter*
}

The unique and special contribution of Sara Mitchell and Andrew Owsiak's article, "Judicialization of the Sea: Bargaining in the Shadow of UNCLOS," is how the authors disentangle the impact of legalization and the impact of judicialization. The UN Convention on the Law of the Sea (UNCLOS) clarified many heretofore ambiguous elements of the law of the sea. For example, the agreement established specific boundaries, rules, and metrics to demarcate land claims of coastal states, and created the category of exclusive economic zones (EEZ). These specifications can be seen as contributions of legalization; once specified in a formal multilateral treaty, all states knew that certain assertions would not be considered legally valid under international law. ${ }^{1}$ Judicialization is different from legalization. Judicialization is the process by which courts and judges increasingly dominate politics, either by directly adjudicating a case or by casting a shadow over the out-of-court political process. ${ }^{2}$ The UN Charter requires states to peacefully resolve their disputes themselves. UNCLOS added that state parties could resort to one of four possible adjudicatory means. If states did not agree to ICJ or International Tribunal for the Law of the Sea (ITLOS) adjudication, and if they also did not agree to arbitration under Annex VIII, then arbitration under Annex VII would be the default. According to Michell and Owsiak, by making one of these four mechanisms compulsory, UNCLOS judicialized the law of the sea. Henceforth, states would bargain over their disagreements knowing that a failure to reach a mutually agreed upon resolution would mean that adjudicators would be tasked with resolving the disagreement. The judicialization claim is that this knowledge impacts out of court diplomatic proceedings.

Mitchell and Owsiak see the act of pre-selecting one of the four adjudicatory mechanisms, or failing to pre-select a mechanism, as sending a signal to other states. As an empirical matter, states that do select "almost always select a court, moving a dispute from default arbitration to adjudication—but only if both states' declarations agree on which court to use." ${ }^{3}$ What the authors want to know is if a dyad of states opt into specific legal mechanisms, and if they opt into a court-option, are they then more likely to resolve their disputes compared to states that either do not specify or that specify different dispute resolution mechanisms? It is at this point that some critics are likely to disagree with the authors.

\footnotetext{
* Norman Dwight Harris Professor of International Relations, Northwestern University, Evanston, Illinois, United States.

${ }^{1}$ Not explicitly mentioned is that legalization also created maritime boundary delimitation disputes. Donald Rothwell's contribution to this symposium explains that in creating EEZs, UNCLOS actually generated 400 overlapping EEZ claims, and thus 400 new maritime delimitation disputes. As Rothwell explains, all involved intended that state parties, not courts, would be used to resolve delimitation disagreements. See Donald R. Rothwell, The Law of the Sea, International Courts, and Judicialization, 115 AJIL Unbound 373 (2021).

${ }^{2}$ Karen J. Alter et al., Theorizing the Judicialization of International Relations, 63 INT'L STUD. Q. 449 (2019).

${ }^{3}$ Sara McLaughlin Mitchell \& Andrew P. Owsiak, Judicialization of the Sea: Bargaining in the Shadow of UNCLOS, 115 AJIL 579,581 (2021).

(C) Karen J. Alter 2021. This is an Open Access article, distributed under the terms of the Creative Commons Attribution licence 368 (http://creativecommons.org/licenses/by/4.0/), which permits unrestricted re-use, distribution, and reproduction in any medium, provided the original work is properly cited.
} 
Mitchell and Owsiak's key finding is that when states select the same adjudicatory option, and especially when they select the same court-option, dispute settlement is most likely to occur. Why sameness of the dispute settlement selection would make it more likely that state-parties resolve their disputes is not self-evident. Mitchell and Owsiak claim that declarations regarding which dispute settlement mechanism is preferred send signals that "change the bargaining behavior of the state parties that make them in three ways." 4 First, having chosen to declare a dispute resolution mechanism signals that states want to bilaterally resolve their disagreements. Even if the states then choose diplomatic or non-binding means of dispute resolution, the declaration itself contributes to the peaceful resolution of the dispute. Second, the declarations meaningfully and consequentially pre-commit states in ways that curtails the use of force. In other words, even though the UN Charter prohibits the use of force to resolve territorial conflicts, the act of declaring the preferred adjudicatory process signals an agreement not to use force. Third, adjudication offers a finality "through a process that does not allow military gains to prejudice adjudicated decisions [so that] the advantages of using military force decline." 5 They further claim that when two parties select a court, "[litigating states hold less control over their dispute's management and outcome" because adjudication is harder to influence compared to arbitration. ${ }^{6}$ This is their judicialization claim. The authors test this claim through a unique dataset that encapsulates interstate diplomatic conflicts, namely the Issue Correlates of War (ICOW) project. $^{7}$

This is a complicated set of arguments to engage for a number of reasons. First, many lawyers will not have the quantitative background to understand the details of the authors' claims, or the tests and figures that allegedly validate their claims. Second, few readers have enough information about the ICOW dataset to know how meaningful the tests are. Third, certain assertions along the way are challenging to accept, including the claim that the sameness of selection matters and claims about how common law or Islamic law states prefer the ICJ to other international courts. ${ }^{8}$ Fourth, the findings rest mostly on a correlation, something which scholars interested in causal inference will find dissatisfying. Fifth, the findings are probabilistic; the study is not a theory of everything. Exceptions can exist without invalidating the overall finding, and there could also be an omitted variable that better explains the outcome.

These concerns, however, are not really valid critiques of the article. The first and second concerns can be resolved by those who do know the statistics and the data. The third issue is not central to the finding of this article, which is to say that these contestable claims could be wrong, yet the overall finding could still be right. The fourth concern about causal inference is more of a wish that the data might allow for a different type of analysis, or that the authors had done this different type of analysis. ${ }^{9}$ The fifth concern reflects a reality that social scientists accept perhaps too readily, and that lawyers often reject too readily.

Social scientists are looking for a correlation that is statistically significant. Typically, scholars will report whether their finding is statistically significant at the five, three, and two percent threshold. In stating the threshold, by definition we know that the finding is likely notvalid five, three, or two percent of the time. Because social scientists readily accept that there will be exceptions to the rule, a lawyer who points out that the argument does not hold for

\footnotetext{
${ }^{4} I d$. at 582.

${ }^{5} \underline{I d}$.

${ }^{6} \underline{I d}$. at 581 . As the authors note: "The courts consequently cast a shadow, within which the disputing states know the court may hear the case, will rule if necessary, can often predict how it will rule, and can decide to settle the case before it does." Id.

${ }^{7}$ Id. at n. 17 (observing that ICOW identifies 270 interstate maritime claims during the period of 1900-2010).

${ }^{8}$ Mitchell is drawing on her earlier work with Emilia Powell. See Sara M. Mrtchell \& Emilia J. Powell, Domestic Law Goes Global: Legal Traditions and International Courts (2011) and Emilia J. Powell, Islamic Laiw and International Law: Peaceful Resolution of Disputes (2020).

${ }^{9}$ See Benjamin J. Appel, Causal Inference, International Law, and Maritime Disputes, 115 AJIL Unbound 389 (2021).
} 
this or that case is not seen as invalidating the larger finding. Yet social scientists do not know how to think about these exceptions. Clearly a theory of war that can account for hundreds of small skirmishes but not WWI or WWII is missing something vital, even if the theory works 98 percent of the time. Social scientists may also be too willing to dismiss a substantive expert who argues that "something else matters." For the social scientist, if something else truly matters, then the scientific method which involves making a claim, and letting others validate or later invalidate the claim by finding the "something else" that matters, will resolve the issue down the line. So, the social scientist may too readily dismiss the counter-example raised by a lawyer, thinking that the lawyer is simply saying, "the argument does not work 100 percent of the time," or that there is either no proof or no way to know if the lawyer's counter-argument invalidates the empirical finding.

The larger point here, however, is that lawyers and social scientists can talk past each other. Lawyers may discuss exceptions, without identifying if or how the exception completely undermines the argument. And social scientists may dismiss the discussion of outlier cases or the claims that the finding is spurious because they lack the details to know if the lawyer's critique is right.

This symposium draws together a diverse range of scholars and viewpoints to engage Mitchell and Owsiak's provocative article. Some of the discussion will exemplify lawyers, practitioners, and social scientists talking past each other. Some of the discussion involves specialists in the law of the sea who bring in details and data that lie outside of Mitchell and Owsiak's scope of analysis. These details may create a counterargument that remains unexplored. In other words, where Mitchell and Owsiak suggest that the signals states have sent each other at the moment they ratified UNCLOS contribute to the peaceful resolution of disputes, legal specialists seem to be seeing that skillful diplomacy and lawyering are really what mattered. All of the contributors-among which there are practitioners, legal scholars, and social scientists-fill in additional ways to consider or explore when and how judicialization is important.

Donald Rothwell of the Australian National University explains that ICJ rulings informed the UNCLOS, and identifies what the UNCLOS agreement then added. Rothwell sees UNCLOS' judicialization as having little impact, because ICJ decisions already defined many of the issues, and because UNCLOS indicates "that delimitation of the exclusive economic zone or the continental shelf is to be by way of agreement between coastal states." ${ }^{10}$ He turns to the salient dispute of Australia's controversy with Timor-Leste, and considers historically specific factors that led conciliation followed by a diplomatic agreement. Implicitly, Rothwell questions the practical utility of a simple signaling argument. While social scientists appreciate and look for parsimonious explanations, practitioners know that law does not work on its own, but rather people, relationships, diplomacy, and processes are critical and necessary parts of resolving difficult disagreements. Although the Australia-Timor Leste example seems to support Mitchell and Owsiak's judicialization claim, Rothwell argues that the historical facts make this case exceptional.

Judge Kriangsak Kittichaisaree from the International Tribunal of the Law of the Seas explores what a judge can learn from Mitchell and Owsiak's social science perspective. ${ }^{11}$ Kittichaisaree agrees that the possibility of adjudication shapes out of court bargaining. Yet, he stresses that states have subjective legal beliefs that they pursue regardless of what legal precedent suggests, and is skeptical that the choice of adjudicatory form is itself all that important. He further suggests that a signaling argument overlooks that Asian countries avoid adjudication, and finds the claims that civil law, common law, and Islamic traditions influence adjudicatory choices implausible. Implicitly, Kittichaisaree is explaining why the choice of adjudicatory venue and the state's legal tradition is not in

${ }^{10}$ Rothwell, supra note 1 , at 373 .

11 Kriangsak Kittichaisaree, Judicialization of the Sea: A Judge's View, 115 AJIL UnBound 378 (2021). 
itself significant for an ITLOS judge. What matters more are the rules themselves, and the ways that the parties engage both the rules and the dispute settlement mechanism.

Áslaug Ásgeirsdóttir of Bates College explains why the uniqueness of UNCLOS makes it doubtful that we can replicate Mitchell and Owsiak's analysis or extend its finding to other international courts and tribunals. ${ }^{12}$ There are twenty-four international courts, so that one could well imagine that a finding about signaling through ratification would be of general significance. Yet Ásgeirsdóttir believes that UNCLOS is an exceptional treaty, that the finding may be unique, and that the finding also may not be all that important since the vast majority of issues and disputes involving UNCLOS are not maritime territorial claims. She is also wary of the finding precisely because it rests on a correlation, and the data and claim do not seem broadly generalizable to the larger set of maritime issues that UNCLOS addresses. Ásgeirsdóttir wants to know why states pre-selected certain adjudicatory mechanisms, and why states may not have pre-selected a mechanism. This question, she argues, can only be answered using qualitative methods.

Benjamin Appel of the University of California San Diego explains how Mitchell and Owsiak's causal argument fails to reach the threshold required for causal inference. ${ }^{13}$ Appel believes that the data and approach introduce a bias that prejudices the finding, and suggests additional controls that would make the finding stronger. Yet, there does not seem to be a way to escape what political scientists recognize as the dreaded and ubiquitous endogeneity problem: if the factor that explains why states pre-select and make a choice may also explain why states then resolve the dispute, one cannot see the act of pre-selection as explaining why a dispute is then resolved. The endogeneity problem is inherent to the UNCLOS agreement: if UNCLOS reflects a state choice to adopt ICJ precedent, to create EEZ rights that then require maritime delimitation, and to require that these delimitations occur via mutual agreement or some form of adjudication, then there is nothing to explain if the state-made recipe is then followed.

Nicole De Silva of Concordia University in Montreal argues that Mitchell and Owsiak's focus on peaceful dispute settlement is too narrow. ${ }^{14}$ International judges have a number of objectives that they further through adjudication, including developing international law and educating participants about the law and the ITLOS legal mechanisms. These multiple objectives are revealed, she argues, when one studies the non-adjudicatory endeavors of ITLOS. She further argues that out of court settlement might actually undermine the achievement of these other goals. Her contribution is an oblique critique of Mitchell and Owsiak who, De Silva suggests, put too much emphasis on whether disputes are peacefully resolved. Circling back to Rothwell, it appears that the intent all along was that maritime delimitations would be peacefully resolved via negotiation. De Silva adds, however, that judicialization operates in more ways that Mitchell and Owsiak suggest, and that adjudication does more than simply "resolve a dispute."

Finally, Theresa Squatrito of the London School of Economics echoes De Silva in finding that international courts—and not just the signals states send—play an important role in resolving disputes. ${ }^{15}$ Squatrito reviews work on the performance of international courts that suggests that not all courts, not all cases, and not all adjudications are the same. Rather the details of the legal process and the performance of judges are important.

$* * * *$

Mitchell and Owsiak's, "Judicialization of the Sea: Bargaining in the Shadow of UNCLOS," is both a challenging and provocative article. Given that Mitchell and Owsiak's finding is correlational and probabilistic, and it rests on

\footnotetext{
12 Áslaug Ásgeirsdóttir, Explaining State Adjudication Choices: Limits on Focusing on Visible Processes, 115 AJIL UnBound 384 (2021).

13 Appel, supra note 9.

${ }^{14}$ Nicole De Silva, International Courts' Shadow Effects and the Aims of Judicialized International Cooperation, 115 AJIL UNBOUND 394 (2021).

15 Theresa Squatrito, International Judicial Performance and the Law of the Sea, 115 AJIL UnBound 399 (2021).
} 
an analysis of 270 disputes over a 110-year period, it is understandable that participants in the dispute resolution process will believe that legal and political skill and timing make all the difference. Meanwhile, both the authors' claim and the critiques could be right: a relatively small number of state-dyads pre-committed and made the same adjudicatory choice. ${ }^{16}$ The signals could matter in the ways the authors claim, even if the dispute is then resolved diplomatically. But it could also be that factors other than the initial signals sent by states indicating the adjudicatory mechanism are decisive.

None of the contributions to this symposium challenge the authors' larger claim that UNCLOS' legalization and judicialization contributes to the peaceful resolution of maritime delimitation disputes. Yet it is also a problem that for their analysis that it does not matter when or how the dispute is resolved, just that the dispute is peacefully resolved. Clearly, as the Timor Leste and Australian maritime dispute shows, the timing is important for the goals of peace, justice and economic development. The development of international law relating to the oceans, and the many other issues that the UNCLOS regime helps to address are also important. Indeed, if one believes that most disputes are or will be peacefully resolved, then perhaps the focus on maritime delimitation distracts more than it illuminates.

I doubt that Mitchell and Owsiak would disagree that diplomats, lawyers and judges, timing, and process are also very important in dispute settlement. Nor would they disagree that their probabilistic story is not enough of an explanation. In my view, the best way to think about Mitchell and Owsiak's contribution is that they are demonstrating that legalization and judicialization matter, and their causal mechanism is at best one piece of the story. Even when symposium participants disagree with Mitchell and Owsiak, the direction of their disagreement is to develop additional ways that legalization and judicialization are legally, politically, and substantively consequential.

As a collective, the article and this symposium suggest that UNCLOS' legalization and judicialization change state incentives; create new issues, interests and actors; develop international law; and provide institutional mechanisms to address a vast array of issues involving the oceans. Ironically, the fact that there is so little interstate conflict as a result of these developments can make UNCLOS a less interesting topic for international legal scholars and political scientists. These many contributions, in the view of those who take the time to understand the details, make UNCLOS one of the most interesting and significant post-war international law success stories.

\footnotetext{
${ }^{16}$ Mitchell and Owsiak report that: "As of December 2020, 179 of 194 (or 92 percent) states had signed UNCLOS, while 164 (or 92 percent of signatory) states ratified the convention. A small number of these state parties have active Article 287 declarations. Forty-seven (or 29 percent of) ratifying states recognize the jurisdiction of ITLOS, the ICJ, Annex VII arbitration, or Annex VIII arbitration for compulsory dispute settlement: thirty-nine states parties for ITLOS, twenty-eight for the ICJ, ten for Annex VII, and eleven for Annex VIII." Mitchell \& Owsiak, supra note 3, at 581. Kittichaisaree's contribution provides a table indicating which states made which choice. See Kittichaisaree, supra note 11.
} 